\title{
DINAMIKA PERTUMBUHAN GEREJA BAGI PELAYANAN HAMBA TUHAN GKSI SEKTOR KARAMA-SULAWESI BARAT
}

\author{
Malik, Widya Wahyuni \\ Sekolah Tinggi Teologi Injili Arastamar (SETTIA) Jakarta \\ malikbambangan@gmail.com
}

Diterima:
18-11-2020
Direvisi:
23-11-2020
Diterbitkan:
29-12-2020
Keywords:
Growth, church,
coaching,
congregation
Kata Kunci:
pertumbuhan,
gereja,
pembinaan,
inmnnt

\section{ABSTRACT}

The effort to manifest the growing church in the ministry of every servant of God is a calling as well as a demand for every servant of God in their ministry. However, not a few have failed in this case due to several factors. Some of these factors come from outside the church, but some come from within the church itself. To deal with this, good management is needed to handle it: The purpose of this study was to determine the dynamics of church growth for the ministry of the Servant of the Gereja Kristen Setia Indonesia in the Karama Sector, Kalumpang sub-district, Mamuju district, West Sulawesi. The approach used is observation with the interview method and providing outreach to the authorities then providing guidance to God's servants. As a result, there is a need for guidance for God's servants to uphold the dynamics of church growth both in quality and quantity towards the growth of congregational faith.

\section{ABSTRAK}

Upaya perwujudan gereja yang bertumbuh dalam pelayanan setiap hamba Tuhan merupakan panggilan sekaligus tuntutan bagi setiap hamba Tuhan alam pelayanan mereka. Namun tidak sedikit yang menemui kegagalan dalam hal ini karena disebabkan oleh beberapa faktor. Beberapa faktor itu ada yang datang dari luar gereja, namun ada juga yang bersasal dari dalam gereja itu sendiri. Untuk menghadapi hal ini maka perlu manajemen yang baik untuk menanganinya. Tujuan penelitian ini adalah untuk mengetahui bagaimana dinamika pertumbuhan gereja bagi pelayanan hamba Tuhan Gereja Kristen Setia Indonesia di Sektor Karama, kecamatan Kalumpang kabupaten Mamuju Sulawesi Barat. Adapun pendekatan yang digunakan adalah observasi dengan metode wawancara dan memberikan sosialisasi kepada pihak yang berwewenang kemudian mengadakan pembinaan kepada para hamba Tuhan. Sebagai hasil bahwa sangat diperlukan pembinaan bagi para hamba Tuhan untuk menunjung dinamika pertumbuhan gereja baik secara kualitas maupun secara kuantitas menuju pertumbuhan iman jemaat. 


\section{PENDAHULUAN}

Pertumbuhan gereja adalah merupakan topik yang sangat penting dibicarakan dalam setiap Gereja, karena semua orang Kristen berharap gerejanya menjadi lebih baik atau paling tidak lebih baik daripada yang sekarang. Namun kondisi umum yang terjadi dari sebahagian besar gereja adalah, walaupun gereja bergerak maju, segalanya terjadi sangat lambat. Mengapa demikian? Bukankah semua yang diperlukan gereja untuk bertumbuh telah disediakan Allah? Masalahnya adalah karena orang Kristen tidak memanfaatkannya, malahan berusaha mendorong dan menarik gereja dengan kekuatan sendiri.

Beberapa gembala dari gereja yang bertumbuh menyampaikan rahasia sukses mereka bisa berupa corak ibadah yang dapat menjangkau orang yang belum biasa ke gereja. Yang lain berkeyakinan bahwa kunci pertumbuhan Gereja terletak pada pembinaan bagi orang percaya yang konsisten. Ada juga yang mengutamakan metode pemasaran gereja. Semua jawaban itu kedengarannya meyakinkan, tetapi kadang-kadang jawaban itu saling bertentangan dan menambah kebingungan. Akan tetapi menurut pengamatan sementara dari peneliti, perkembangan gereja atau pertumbuhan suatu gereja akan menjadi maju dan pesat jika gereja itu memiliki program yang mampu menjangkau, memuridkan (pemuridan) serta menggembalakan, dan ketiga hal ini sangat berkaitan erat satu sama lain. Inilah bisa diakatakan sebagai pilar dalam pertumbuhan gereja.

Hal ini dapat dipelajari melalui elemen-elemen yang membuat sebuah gereja bertumbuh dengan sebuah pendekatan. Pendekatan ini tidak berorientasi pada model tetapi berorientasi pada prinsip. Model adalah suatu konsep yang diterapkan oleh satu atau kadang-kadang banyak gereja dan berhasil secara positif. Sedangkan prinsip adalah elemen yang sudah terbukti berlaku pada semua gereja yang bertumbuh di seluruh dunia.

Christian A. Schwarz (1999:34) mempelajari sedikitnya 1000 gereja yang berbeda di lima benua untuk memperoleh elemen prinsip bagi pertumbuhan gereja. Gereja-gereja di 32 negara telah berpartisipasi. Kusioner yang harus diisi oleh 30 anggota di tiap gereja, diterjemahkan ke dalam 18 bahasa yang berbeda dan menganalisis 4,2 juta jawaban. Akhirnya Schwarz menyampaikan delapan prinsip yang paling penting bagi pertumbuhan gereja yang diantaranya; kepemimpinan yang melakukan pemberdayaan, pelayanan yang berorientasi pada karunia, kerohanian yang haus dan penuh antusiasme, struktur pelayanan yang tepat guna, ibadah yang membangkitkan kerohanian, kelompok kecil yang menjawab kebutuhan secara menyeluruh, penginjilan yang berorientasi kepada kebutuhan dan hubungan yang penuh kasih.

\section{METODE PENELITIAN}

Locus penelitian ini terletak di Desa Batu Makkada Kecamatan Kalumpang Kabupaten Mamuju Sulawesi Barat. Setelah mendapatkan surat tugas dari SETIA Jakarta, maka langkah pertama adalah mengadakan pelaporan diri sekaligus sosialisasi tentang maksud dan tujuan penelitian ini kepada pemerintah setempat, BPW GKSI Sulbar dan Pengurus Sektor GKSI Karama. Kemudian tim mengadakan sosialisasi dan komunikasi kepada Jemaat secara khusus jemaat GKSI Bosokan dan Bau yang secara geografis berada pada wilayah desa yang sama yakni desa Batu Makkada. Alasan pemilihan dua jemaat ini karena letak kedua jemaat tersebut berdekatan dan juga berada dalan sektor yang sama yakni sektor Karama. Setelah mengadakan sosialisasi kemudian tim melakukan pembinaan untuk mencapai maksud tersebut dalam penelitian ini. Sebagai hasil daripada kegiatan tersebut, pada akhirnya tim menyusun hasil kegiatan penelitian dalam bentuk artikel ini. 


\section{HASIL DAN PEMBAHSAN}

Gereja yang ingin bertumbuh dalam Kristus, tidak boleh mengabaikan salah satu pun dari karakteristik ini.

\section{Kepemimpinan yang melakukan pemberdayaan}

Karakterisitik yang pertama tidak disebut kepemimpinan yang diberdayakan tetapi yang melakukan pemberdayaan. Kepemimipinan yang diberdayakan dapat diartikan dengan adanya satu tokoh pemimpin (kadang-kadang beberapa) dengan bakat yang luar biasa serta memiliki visi yang besar. Hal ini akan terlihat seorang pemimpin yang sangat sibuk luar biasa karena bekerja hanya seorang diri. Bawahan hanya akan bekerja jika diberi perintah oleh pimpinan. Inilah pola kepemimpinan yang tidak memberdayakan orang lain.

Melakukan pemberdayaan berarti, para pemimpin gereja yang bertumbuh tidak harus berusaha untuk membangun kekuasaan untuk menjadi sangat dominan. Sebaliknya, salah satu dari tugas mereka yang terpenting adalah menolong orang Kristen mengembangkan tingkat kemampuan yang telah dikaruniakan Allah kepada mereka. Pemimpin gereja memperlengkapi, mendukung, memotivasi dan menjadi mentor bagi individu-individu sehingga mereka menyadari bahwa Allah mempunyai panggilan yang unik bagi setiap orang.

\section{Pelayanan yang berorientasi pada karunia}

Dasar dari karakteristik yang kedua ini adalah keyakinan bahwa Allah telah menetapkan orang-orang tertentu yang paling tepat melakukan pelayanan tertentu di gereja. Peran pemimpin gereja adalah membantu anggotanya mengenali karunia mereka dan memadukan mereka ke dalam pelayanan yang cocok dengan karunia mereka. Prinsip ini kedengarannya sangat sederhana, tetapi bila diterapkan akan membawa dampak besar bagi semua bidang kehidupan gereja. Ketika kita hidup menurut karunia rohani kita, kita tidak lagi bekerja dengan kekuatan kita sendiri, tetapi Roh Kudus bekerja di dalam kita. Jadi walaupun kita adalah orang biasa, kita dapat menggenapi hal-hal yang luar biasa.

\section{Kerohanian yang haus dan penuh antusiasme}

Karakteristik yang lain yang berhubungan erat dengan pertumbuhan gereja adalah adanya gaya kerohanian. Bukan tentang bagaimana kerohanian itu diekspresikan, melainkan fakta atau kenyataan bahwa iman dihayati dan diamalkan berdasarkan komitmen, yang berapi-api dan antuasiame. Tingkat kehausan rohani sangat mennetukan pertumbuhan gereja.

Karakteristik ini menjelaskan bahwa metode yang digunakan oleh sebuah gereja adalah masalah sekunder dan masalah primer. Gereja dalam menjalanni imannya dengan penuh kegairahan rohani akan mengalami sukses walaupun dengan memakai metode yang sederhana atau yang biasa. Begitu juga dengan sebaliknya bahwa metode yang dianggap paling terbaik sekalipun namun tidak terdapat kegairahan rohani di dalamnya maka hasilnya tidak akan maksimal. Ibarat suatu alat yang canggih namun tidak pernah diisi bahan bakar, maka tentu tidak akan beroperasi.

\section{Struktur pelayanan yang tepat guna}


Karakteristik ini merupakan suatu kriteria yang sangat penting untuk bentuk dan struktur di dalam gereja. Meski struktur gereja, bukanlah sebuah tujuan, namun ia merupakan sarana untuk mencapai suatu tujuan. Oleh karena itu, bentuk atau struktur yang tidak tepat guna, haruslah diperbaharui (mis. Struktur kepemimpinan yang merendahkan harkat dan martabat, waktu ibadah yang tidak tepat, atau program yang tidak menjangkau jemaat secara efektif). Melalui proses pembaharuan ini, kebiasaan yang hanya bersifat tradisional dapat dipertahankan bila masih efektif. Tradisonalisme berarti bentuk gereja harus tetap sama karena sudah terbiasa dengan bentuk atau pola atau model tersebut. Tradisionalisme merupakan faktor yang paling besar akibat negatifnya dalam pertumbuhan gereja. Hal inilah yang menghambat pertumbuhan gereja. Gereja masih tertutup dengan kemajuan, baik itu yang sudah ada disekitarnya, maupun yang datang dari luar lingkungan. Gereja ini nmasih tetap terpaku dengan sistem yang lama dan tetap terpaku pada program yang sudah ada (program oriented) dan tidak peka terhadap kebutuhan pelayanan yang mendesak untuk dilayani pada saat itu (people oriented). Ada indikasi bahwa untuk melayani orang sakitpun harus dirapatkan dulu karena kalau tidak ada dalam program tahun ini, maka tidak akan dilayani. Sebenarnya gereja ini sudah menuju staqnansi (berjalan ditempat) dan akhirnya menuju kehancuran.

\section{Ibadah yang membangkitkan Kerohanian (KKR)}

Banyak orang Kristen yang memakai model ibadah tertentu dari gereja tertentu, karena model tersebut dianggap sudah mewakili prinsip pertumbuhan gereja. Karakteristik ini sebenarnya tidak menunjuk kepada sebuah model ibadah, melainkan menunjuk kepada suatu prinsip yang harus ada dalam setiap ibadah raya. Hal yang menjadi kriteria utama dalam ibadah adalah; apakah ibadahnya merupakan pengalaman yang membangkitkan isnpirasi atau semangat baru bagi mereka yang menghadirinya? Dan pada akhirnya mereka yang hadir dalam ibadah yang mengalami kebangkkitan semangat akan berkata- sangat luar biasa ibadah kita ini, saya tidak mau ketinggalan lagi dalam ibadah raya ini. Jika hal seperti ini ada dalam setiap ibadah di gereja anda, maka bersipalah gereja anda dipenuhi dengan orang-orang yang semangat untuk beribadah.

Menciptkan ibadah yang membangkitkan semangat kehidupan rohani jemaat, memang seringkali mendapat tantangan dari kelompok Kristen yang biasa beribadah dengan hanya sekedar memenuhi tuntutan agamanya. Mereka datang beribadah bukan dengan suatu kerinduan yang mendalam untuk menikmati persekutuan dengan Tuhan dan sesama serta untuk mendapatkan pengalaman yang mendalam bersama dengan Tuhan, namun hal itu dilakukan hanya untuk kesenangan manusia. Inilah ibadah raya Kristen yang rutinitas. Bahkan beberapa orang percaya mengatakan bahwa dengan kesetiaan mereka bribadah yang tidak menyenangkan Tuhan itu, akan mendapat berkat dari Tuhan. Padahal mereka datang sesudah doa pembukaan dan pulang sebelum doa berkat, mau dapat berkat dari mana? Hal ini menjadi tantangan besar bagi para hamba Tuhan dalam pelayanan di daerah ini (Widya Wahyuni (2020). Selanjutnya perlunya kegiatan KKR ini karena jemaat seakanakan mengalami kemunduran dalam antusiasme beribdadah baik dalam persekutuan kelompok maupun ibadah raya di Gereja (Kristian SP). Oleh sebab itu untuk dapat mewujudkan ibadah yang mengalami kebangunan atau kebangkitan kerohanian, maka perlu ada persiapan rohani dan materi serta tehnik yang baik dan matang.

\section{Kelompok kecil yang menjawab kebutuhan secara menyeluruh}


Gereja-gereja yang bertumbuh biasanya telah mengembangkan suatu sistem kelompok kecil dimana setiap orang Kristen dapat berkomunitas dengan intim, mendapat pertolongan sehari-hari, dan mendapat dukungan pertumbuhan rohani yang intensif. Inilah sesungguhnya elemen-elemen dari konsep keseluruhan Alkitab. Dalam kelompok ini, orang tidak hanya mendalami isi Alkitab, atau hanya mendengarkan uraian yang menarik dari seorang pakar, akan tetapi menreka menerapkan kebenaran Alkitab dalam kehidupan sehari-hari. Kelompok kecilo orang Kristen buklanlah suatu pilihan yang menjadi hobbi semata-mata dan kesenangan yang dilakukan bila ada waktu. Bukan demikian! Hal ini merupakan pokok kehidupan yang sebenarnya dari gereja Yesus Kristus.

\section{Penginjilan yang Berorientasi kepada Kebutuhan}

Dapatkah gereja bertumbuh tanpa proses penyampaian kabar baik untuk membawa orang lain masuk ke dalam Gereja? Pertumbuhan gereja tidak dapat terjadi tanpa penginjilan. Rahasia sukses kita dalam menyampaikan Injil, yakni dengan cara menjawab kebingungan dan memenuhi kebutuhan mereka yang bukan Kristen. Apakah yang menjadi kebutuhan manusia yang masih ada dalam kegelapan dosa? Kebutuhan mereka adalah terang Kristus. Dan terang Kristus itu akan hadir bagi mereka jika ada yang memberitakan Injil kepadanya. Dengan demikian karakteristik gereja yang bertumbuh adalah dengan giat melaksankan penginjilan untuk mencari jiwa baru dibawah kepada Kristus agar beroleh hidup kekal.

\section{Hubungan yang penuh kasih.}

Gereja-gereja yang bertumbuh memanifestasikan kasih sebagai ajaran penting Kristus dan menjadikan ajaran tersebut yang jauh lebih hangat daripada gereja-gereja yang macet dan merosot. Beberapa pertanyaan atau kusioner berikut ini dapat mengevaluasi gereja kita;

1. Apakah anggota jemaat menghabiskan waktu satu sama lain di luar acara resmi yang diadakan oleh gereja?

2. Berapa sering mereka mengundang untuk makan bersama atau untuk minum secangkir kopi?

3. Seberapa murah hati gereja membagikan pujian?

4. Sejauh mana gembala memahami pergumulan pribadi dari para aktivis gereja?

5. Berapa banyak keceriaan terdapat dalam gereja?

Kasih yang nyata dan tidak pura-pura dapat menghidupkan gereja dengan kekuatan daya tarik yang lebih besar dibanding dengan semua upaya dan prinsip pemasaran dunia. Kasih sejati menyebarkan wangi-wangian yang memikat dan sulit untuk menolaknya. Ada beberapa hal yang perlu diperhatikan berkaitan dengan delapan karakteristik pertumbuhan gereja, yaitu:

1. Prinsip-prinsip ini berlaku secara universal (dapat diterapkan pada gereja-gereja di seluruh dunia)

2. Prinsip-prinsip ini dapat diterapkan pada gereja kita sendiri berdasarkan situasi dan kondisi masing-masing gereja.

3. Masing-masing prinsip ini memiliki hubungan yang erat dengan pertumbuhan secara kualitas maupun secara kuantitas di gereja. Jika kita ingin melakukannya, tidak boleh mengabaikan salah satu pun dari delapan prinsip ini. 


\section{KESIMPULAN}

Pertumbuhan gereja adalah sesuatu yang tidak dapat dihasilkan oleh manusia. Tugas saat ini hanyalah menanam dan menyiran seperti apa yang dikatakan oleh Rasul Paulus kepada jemaat di Korintus. Jadi hanya sebagai alat-Nya yang dipakai membangun gerejaNya. Dengan demikian dapat disimpulkan bahwa gereja yang bertumbuh adalah gereja yang memiliki pemimpin berkomitmen dari hati dan jiwa yang diterangi kebenaran Firman Tuhan bagi pertumbuhan gereja. Kehidupan jemaatnya menggunakan karunia-karunia rohani untuk memperbaiki gereja. Mereka hidup berdasarkan iman dengan kuasa dan antusiasme yang kuat. Struktur gereja dievaluasi agar menjadi lebih efektif. Gereja yang bertumbuh ibadah rayanya dipersiapkan menjadi titik puncak bagi mayoritas jemaat. Begitu juga dengan kuasa kasih dan persekutuan dialami dalam setiap kelompok kecil. Dan apada akhirnya seluruh jemaat mengambil bagian dalam memenuhi panggilan Amanat Agung Tuhan Yesus dan kasih Kristus meresap ke dalam semua aktivitas gereja.

Doa dan harapan bersama, supaya gereja kiranya menjadi gereja yang bertumbuh, menjadi berkat dan senantiasa menyenangkan hati TUHAN. Pertumbuhan bukanlah usaha kita, tetapi dari Tuhan. Bagian kita adalah menanam dan menyiramnya (I Kor. 3:6).

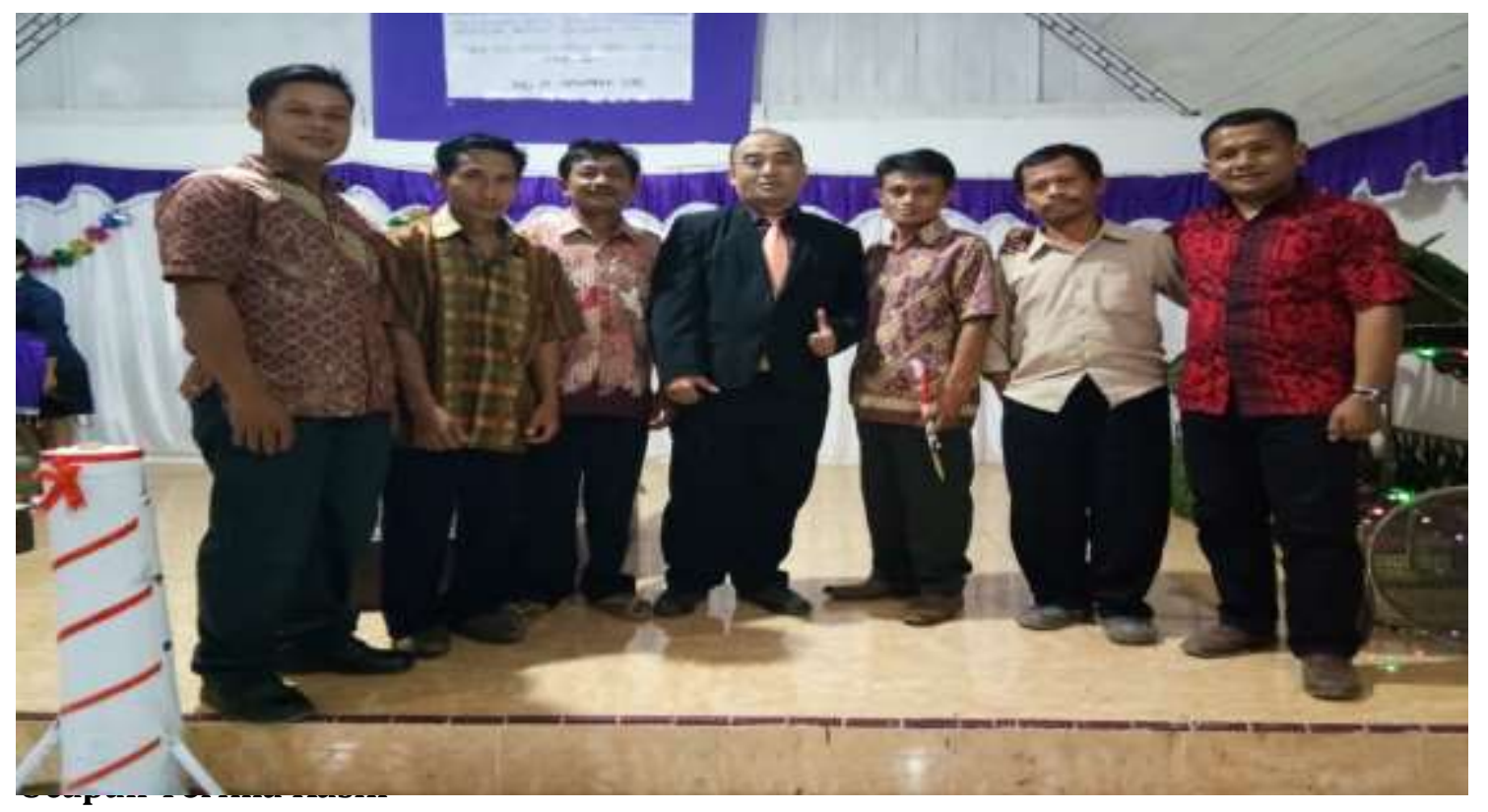

1. Terima kasih Institusi Sekolah Tinggi Teologi Injili Arastamar (SETIA) Jakarta sebagai Wakil Ketua IV (LPMI \& PKM) Ev. Tony Salurante, M.Pd.K., MA.

2. Terima kasih kepada BPS GKSI Jakarta

3. Terima kasih kepada BPW GKSI Sulawesi Barat (Pdt. Aris D. Rimbe, M.Th)

4. Terima kasih kepada Sektor Karama (Pdt. Widya Wahyuni, S.Th)

5. Terima kasih kepada pemerintah Desa Batu Makkada (Marten Manggasa)

6. Terima kasih kepada semua anggota jemaat GKSI di sektor Karama

\section{Referensi}

Schwarz, Christian A, Ringkasan Pertumbuhan Gereja Alamiah (Jakarta:Yayasan Media Buana Indonesia, 1999), 34. 
Abineno, Jemaat. Jakarta: BPK Gunung Mulia, 1987.

Goodwin II, Bennie E., Rahasia Kepemimpinan Yang Efektif , Jakarta : Perkantas, 1991.

Griffiths, Michael, Gereja dan Panggilannya Dewasa Ini, Jakarta: BPK Gunung Mulia, 1993.

Ray, David R., Gereja Yang Hidup, Jakarta: PT BPK Gunung Mulia, 2009.

Saragih, Jahenos, Manajeman Kepemimpinan Gereja, Jakarta: Suara GKY Peduli Bangsa, 2009.

Tedjo, Tony, Church Growth Through Cell Group/Gereja Mula-mula sebagai dasar Pertumbuhan Kelompok Sel dalam Gereja Masa Kini, Yogyakarta: Andi, 2014.

Warren, Rick, Pertumbuhan Gereja Masa Kini, Malang: Gandum Mas, 1999.

Wilson, Gerald, Intepersonal Growth Through Communication, Dubuque: WCB Publisher, 1985.

Wongso, Peter, Tugas Gereja dan Misi Masa Kini, Malang: Seminar Alkitab Asia Tenggara, tahun 1999.

Zaluchu, Fotarisman, Kepemimpinan Dalam Nama Tuhan, Yogyakarta: Gloria Graha, 2003.

Widya Wahyuni, Wawancara Ketua Sektor Karama, 8 Juni 2020

Kristian SP, Wawancara dengan Majelis GKSI Bosokan, 15 Juni 2020 